\title{
Determining the genotoxicity of an aqueous infusion of Bauhinia monandra leaves
}

\author{
Márcia Fernanda Silva Macêdo, ${ }^{1}$ Herbert A. A. A. C. N. Sisenando, ${ }^{1,3}$ Jana Dara F. \\ Queiroz, ${ }^{1}$ Adriana C. C. Argolo, ${ }^{2}$ Ana Conceição R. Dantas Saturnino, ${ }^{2}$ Luana C. B. B. \\ Coelho, ${ }^{2}$ Sìlvia R. Batistuzzo de Medeiros ${ }^{*, 1,3}$
}

${ }^{1}$ Departamento de Biologia Celular e Genética, Centro de Biociência, Universidade Federal do Rio Grande do Norte, Caixa Postal 1575, 59072-970 Natal-RN, Brazil,

${ }^{2}$ Departamento de Bioquímica, Centro de Ciências Biológicas, Universidade Federal de Pernambuco, 50670-420, Recife-PE, Brazil,

${ }^{3}$ Programa de Pesquisa e Pós-Graduação em Ciências da Saúde, Universidade Federal do Rio Grande do Norte, 59072-970 Natal-RN, Brazil

\begin{abstract}
RESUMO: "Determinação da genotoxicidade do infuso aquoso das folhas da Bauhinia monandra". Bauhinia monandra, popularmente conhecida como "pata-de-vaca", é nativa da Ásia e amplamente utilizada em todo o mundo para o tratamento de várias doenças, em especial diabetes. Diante da grande utilização dessa planta no Brasil, e de forma a satisfazer a necessidade de regulamentação das plantas medicinais pelo Ministério Público de Saúde, objetivamos determinar a genotoxicidade, citotoxicidade e mutagenicidade do infuso aquoso das folhas da B. monandra. Os resultados foram correlacionados com os compostos químicos encontrados após realização de uma triagem fitoquímica. Os testes foram realizados em sistema in vitro como o DNA plasmidial, na presença e ausência de exonuclease III, e in vivo empregando sistema procarioto (transformação com bactérias competente DH10B) e eucarioto (teste Allium cepa). As concentrações do infuso foram $0,8 \mu \mathrm{g} / \mu \mathrm{L}, 4 \mu \mathrm{g} / \mu \mathrm{L}, 20 \mu \mathrm{g} / \mu \mathrm{L}$ e $100 \mu \mathrm{g} / \mu \mathrm{L}$. Nessas concentrações o infuso não causou mutagenicidade ou citotoxicidade, porém as concentrações mais elevadas foram capazes de induzir quebra nas ligações fosfodiéster do DNA e formar sítios abásicos, efeito sugerido pela presença de hidroxilas fenólicas. Os resultados revelaram riscos e benefícios desse extrato vegetal para uso terapêutico e seus efeitos sobre integridade do material genético, especialmente quando empregados como hipoglicêmico.
\end{abstract}

Unitermos: Bauhinia monandra, Leguminosae, mutagenicidade, citotoxicidade, genotoxicidade, Escherichia coli, teste de micronúcleos.

\begin{abstract}
Bauhinia monandra, commonly known as "cow's-foot", is native from Asia and widely used all over the world to treat a variety of illnesses, in particular diabetes. The high usage of the plant in Brazil and to fulfill the need of medicinal plant regulation by the Ministry of Public Health, we aimed at determining the genotoxicity, cytotoxicity and mutagenicity of an aqueous infusion from $B$. monandra leaves. The results were correlated to the chemical compounds found after phytochemical selection. Tests were performed in an in vitro system with plasmid DNA, in the presence and absence of exonuclease III, and in vivo system employing prokaryotic (transformation into competent DH10B bacteria) and eukaryotic (Allium cepa) assays. The infusion concentrations were $0.8 \mu \mathrm{g} / \mu \mathrm{L}, 4 \mu \mathrm{g} / \mu \mathrm{L}, 20 \mu \mathrm{g} / \mu \mathrm{L}$ and $100 \mu \mathrm{g} / \mu \mathrm{L}$. The infusion concentrations did not cause mutagenicity or cytotoxicity, however the highest concentrations were able to induce breaks in DNA phosphodiester bonds and form abasic sites, an effect suggested by the presence of phenolic hydroxyls. The results revealed risks and benefits of plant extracts for therapeutic use and their effect on genetic integrity, especially when commonly employed as a hypoglycemic.
\end{abstract}

Keywords: Bauhinia monandra, Leguminosae, mutagenicity, cytotoxicity, genotoxicity, Escherichia coli, micronucleus assay.

\section{INTRODUCTION}

Plant-derived products are an important therapeutic resource in the treatment of many illnesses, especially in developing countries. Data from the World Health Organization (WHO, 2000) show that $70-80 \%$ of the world's population use alternative medicine (Chan,
2003). The socioeconomic conditions of the Brazilian population along with the vast medicinal flora in the country have led a growing number of people to make therapeutic use of plant extracts.

The genus Bauhinia, known as "cow'sfoot" or "ox nail", belong to the family Leguminosae (Caesalpiniaceae), and is among the countless plant 
species of medicinal interest. Bauhinia consists of approximately 300 species (Miyake et al., 1986) mainly distributed in tropical areas of the planet. They are widely used in Brazil and in other countries to treat various diseases, especially infections, pain processes and diabetes. Particularly prominent are aqueous extracts of the leaves, stalks and roots of $B$. cheilantha, $B$. forficata, B. monandra, B. glabra, B. rufescens, B. splendens and B. ungulata (Achenbach et al., 1988; Ritter et al., 2002; Pereira et al., 2004; Macedo and Ferreira, 2004; Morais et al., 2005; Silva et al., 2006; Agra et al., 2007; Agra et al., 2008).

B. monandra is distinguishable from other species by its hypoglycemic activity, proven when administered at $10 \%$ dry leaf extract $(100 \mu \mathrm{g} / \mu \mathrm{L})$ (Minto and Pereira, 2000), the concentration used by popular medicine. Studies performed on malnourished mice demonstrate the plant's capacity to restore normal insulin secretion; also shows considerable antioxidant activity, and is capable of acting on free radicals in cells (Argôlo et al., 2004). Although some compounds of the species have been isolated and identified, there are few studies correlating the biological and adverse effects of its continuous use.

Assays performed on other medicinal species correlate the presence of certain chemical plant substances to cytotoxic and genotoxic damage. Some are capable of causing bacterial mutations and can potentially slow the development of cancers in humans (Agner et al., 1999). Several plants have already had their genotoxic studied, such as Schinus terebinthifolius extract (Carvalho et al., 2003), the methanol extracts from whole plants of Helichrysum simillimum, Helichrysum herbaceum and Helichrysum rugulosum, which indicated mutagenicity (Reid et al., 2006). The detection and evaluation of damage caused by toxic plant components is important in reducing risk when used therapeutically, particularly during prolonged treatment (Cardoso et al., 2006).

The aim of this work was to perform a phytochemical survey of aqueous extract obtained from dried $B$. monandra leaves and determine its cytotoxic, genotoxic, and mutagenic potential through in vitro and in vivo assays with prokaryote and eukaryote systems, to minimize possible human health risks.

\section{MATERIAL AND METHODS}

\section{Sample}

Leaves of $B$. monandra Kurz were collected from ornamental trees at Banco de Germoplasma de Plantas Medicinais na Estação Experimental de Itapirema (Goiana City, State of Pernambuco, Northeast of Brazil). The botanical classification of registered species was recorded as $n^{\circ} 57462$, IPA, at the "Dárdano de Andrade Lima" (Empresa Pernambucana de Pesquisa Agropecuária, Recife, Brazil). The leaves were roughly ground and dried at a constant weight. The infusion with a concentration of $200 \mu \mathrm{g} / \mu \mathrm{L}$ was prepared according to the description in the Farmacopéia dos Estados Unidos do Brasil $2^{\text {nd }}$ Edition (1959). It was filtered through filter paper, sterilized using a $0.45 \mu \mathrm{m}$ acetate filter (Millipore, São Paulo), separated into aliquots in $2 \mathrm{~mL}$ microtubes and stored at $-20^{\circ} \mathrm{C}$.

\section{Plasmid and bacterial strains}

The pBCKS plasmid was derived from the pBluescript $^{\circledR}$ II phagemid and the ampicillin-resistant gene was replaced with the chloramphenicol-resistant gene.

Escherichia coli $\mathrm{DH} 10 \mathrm{~B}$ used in the bacterial transformation test was of the DH10B Genotype: F$m c r \mathrm{~A} \Delta(m r r-h s d \mathrm{RMS}-m c r \mathrm{BC}) \varphi 80 l a c \mathrm{Z} \Delta \mathrm{M} 15 \Delta l a c \mathrm{X} 74$ deo $\mathrm{R}$ rec $\mathrm{A} 1$ end $\mathrm{A} 1$ ara $\mathrm{D} 139 \Delta($ ara, leu $) 7697$ gal $\mathrm{U}$ galK $\lambda$-rpsL nup G /bMON14272/pMON7124.

\section{Phytochemical selection}

The phytochemical selection of dried $B$. monandra leaves was performed by precipitation and coloration reactions as proposed by Professor S. J. A. Matos and colleagues at the Faculdade de Farmácia e Bioquímica, Universidade Federal do Ceará - UFC/Brazil (Matos, 2000). The qualitative analysis of secondary metabolites were performed with $B$. monandra leaves dried and stabilized in an incubator between $40{ }^{\circ} \mathrm{C}$ to $45^{\circ} \mathrm{C}$ for $24 \mathrm{~h}$. The chemical groups were: cyanogenetic heteroside, lactone, including coumarins, quinone, catechin, steroid and/or triterpenoid/carotenoid, resin, alkaloid, organic acids and bases, phenol, saponin, tannin, gum and mucilage, tannins or other substances containing phenol hydroxyls, proanthocyanidin, pyrogallic tannin, flavone heteroside, mucilage. Dehydrated material was powdered; following aqueous and alcoholic extracts were prepared and used in the assays described below.

\section{Alcohol extraction}

B. monandra ethanol leaf extract was obtained by addition of alcohol $94.6{ }^{\circ} \mathrm{GL}(200 \mathrm{~mL})$ to dust from dried leaves $(20 \mathrm{~g})$, for about 10 minutes. The mixture was then filtered through a funnel to produce an ethanol extract.

\section{Aqueous extraction}

Boiling water was added to $20 \mathrm{~g}$ of the drug for extraction (rapid decoction) and allowed to stand for approximately $10 \mathrm{~min}$. The mixture was filtered in a cotton wool-lined funnel and the solution was concentrated to $10 \%(200 \mathrm{~mL})$. The color and smell were observed. 
Analysis of the occurrence of breaks in plasmid DNA

The pBCKS plasmid is a derivation from pBluescript ${ }^{\circledR}$ II phagemid, had approximately 3400 base pairs and the following characteristics: a b-galactosidase ORF (Open Reading Frame), T7 promoter transcription initiation site, a multiple cloning site, a T3 promoter transcription initiation site, fl (-) origin of singlestranded DNA replication (for secretion as singlestranded DNA packaged phages), chloramphenicol resistance ORF, a Lac promoter and a bacterial origin of replication (Flieger et al., 2004).

The vector preparation was performed according to the alkaline method described by Sambrook et al. (1989). After plasmid treatment with the infusion, we were able to determine the presence or not of breaks in the DNA phosphodiester bonds through agarose gel electrophoresis. The plasmid $(1 \mu \mathrm{g})$ was incubated at 37 ${ }^{\circ} \mathrm{C}$ for 1 hour with up to $100 \mu \mathrm{g} / \mu \mathrm{L}$ of the $B$. monandra infusion in a final volume of $20 \mu \mathrm{L}$. The treated plasmid was electrophoresed at $80 \mathrm{~V}$ in $0.7 \%$ agarose gel, containing ethidium bromide $(0.5 \mu \mathrm{g} / \mathrm{mL})$ in 1 XTBE buffer $(90 \mathrm{mM}$ Tris, $90 \mathrm{mM}$ boric acid, $2 \mathrm{mM}$ EDTA, $\mathrm{pH}$ 7). The assay included a negative control (distilled water plasmid) and a positive control (plasmid treated with Bam $H I$ ). The bands were visualized with an UV transilluminator and then photographed with a Kodak EDAS290 system.

\section{Abasic site assay with exonuclease III}

The exonuclease III enzyme has two distinct functions: as an exonuclease hydrolyzing the DNA phosphodiester bond, and as an endonuclease hydrolyzing the DNA phosphodiester bonds at AP sites. The enzyme and its buffer are combined with distilled water to form the MIX, from which $10 \mu \mathrm{L}$ is separated and incubated at $37^{\circ} \mathrm{C}$ for 1 hour with $10 \mu \mathrm{L}$ of each sample analyzed in the DNA plasmid test. After incubation, $10 \mu \mathrm{L}$ is removed from the samples, $2 \mu \mathrm{L}$ of bromophenol blue is added and the mixture is placed in $0.7 \%$ agarose gel and electrophoresed and photographed as described above.

\section{Bacterial transformation}

For the survival assay, the pBCKS - treated as described above, were transferred, by electroporation $(25$ $\mu \mathrm{F} 200 \Omega 1800 \mathrm{~V}$ ), into Escherichia coli DH10B. Cells were plated in LB medium and grown overnight at $37^{\circ} \mathrm{C}$ in the presence of X-gal $(1.6 \mu \mathrm{g} / \mathrm{ml})$ and chlorophenicol $(25 \mu \mathrm{g} / \mathrm{mL})$ for a blue/white and resistance selection, respectively. The survival rate was calculated from the ratio between the number of colonies with the treated plasmid and the number of colonies with the untreated plasmid control. Positive control was the Plasmid DNA digested by Bam HI. All these experiments were performed in triplicate and the significance of the results was tested by analysis of variance and the Tukey test (Sokal and Rohlf, 1995).

\section{Allium cepa assay}

In order to observe whether $B$. monandra infusion was able to generate micronucleus, the Allium cepa test was performed according to Ma et al. (1995). Onions were germinated for 48 hours in distilled water and then treated with $B$. monandra infusion at concentrations of $0.0 \mu \mathrm{g} / \mu \mathrm{L}, 0.8 \mu \mathrm{g} / \mu \mathrm{L}, 4 \mu \mathrm{g} / \mu \mathrm{L}, 20 \mu \mathrm{g} /$ $\mu \mathrm{L}$ and $100 \mu \mathrm{g} / \mu \mathrm{L}$ for 24 hours (five onions per sample), followed by a $24 \mathrm{~h}$ recovery time in distilled water. The roots were then collected and treated with a $3: 1$ solution of ethyl alcohol and frozen acetic acid and underwent hydrolysis in $1 \mathrm{~N} \mathrm{HCl}$ at $60^{\circ} \mathrm{C}$ for 10 minutes. Coloration was achieved using Schiffs reactive. The roots were washed in sulfur water and placed on slides with a few drops of $45 \%$ acetic acid. The cowl was removed and the F1 area gently soaked before placing the coverslip. For each onion, 3000 cells were analyzed for micronuclei, totaling 15000 per sample. One slide was prepared per bulb and all slides were coded and examined blind using bright-field microscopy at a total magnification of 40x.

\section{RESULTS}

Phytochemical selection confirmed the presence of a number of therapeutically significant compounds in the alcoholic and aqueous solutions, including: lactones, steroids, triterpenoids, resins, alkaloids, acids, organic bases and saponins, gums, mucilage, phenol hydroxyls, proanthocyanidins, tannins (hydroxyphenols) and pyrogallic tannins.

A cell- free assay was performed with plasmid pBCKS, with the objective of intervening if the compounds present in the $B$. monandra extract were able to generate breaks or abasic sites on DNA. The pBCKS was treated with different concentrations of the infusion. Results of the plasmid DNA test showed breaks in the phosphodiester DNA bonds at concentrations of $20 \mu \mathrm{g} /$ $\mu \mathrm{L}$ and $100 \mu \mathrm{g} / \mu \mathrm{L}$, converting some of its supercoiled DNA (form I) to nicked circular DNA (form II) (Figure 1). Even generating breaks on the phosphodiester bound it does not exclude the possibility that other types of damages could be occurring. To access whether abasic sites were generated by $B$. monandra infusion, after the treatment of $\mathrm{pBC}$ with this infusion, they were incubated at $37{ }^{\circ} \mathrm{C}$ with an AP. The results showed changes in plasmid DNA conformation at concentrations of $4 \mu \mathrm{g} /$ $\mu \mathrm{L} 20 \mu \mathrm{g} / \mu \mathrm{L}$ and $100 \mu \mathrm{g} / \mu \mathrm{L}$, as seen in Figure 2 .

Another test employed was to see whether $B$. monandra infusion could generate other lesions that could block replication or induce mutations, treated plasmid DNA with this infusion were transformed into 
DH10B strain. Neither cytotoxicity nor mutagenic potential (presence of white colonies) were observed (Table 1).

The analyses of micronuclei in $A$. серa showed no increase in the frequency of small acentric chromosome fragments or whole chromosomes in any of the concentrations tested, suggesting there were no chromosome breaks or disturbances in mitotic spindle (Table 2).

\section{DISCUSSION}

Determination of the safety of natural products is very important since toxicity represents an important obstacle in drug development. In the ethnopharmacological context, the lack of toxicity and genotoxicity are important for the whole population.

Diabetes affects about 10 million Brazilians and is the fourth leading cause of deaths worldwide (WHO, 2000). The $B$. monandra leaf infusion is highly used as a diabetes treatment and in this study it was characterized according to its cytotoxic, genotoxic and mutagenic potential.

There are many plant extracts that reduce the blood-glucose level and the large number of chemical groups shows that various activity mechanisms are involved in lowering the blood-glucose level. Some of these substances may have therapeutic value, while others can cause hypoglycemia as a side-effect owing to their toxicity, particularly hepatotoxicity (Pérez Gutiérrez, 2002; Lamba et al., 2000).

In vitro analysis with plasmid DNA has been widely used to determine breaks in DNA molecule caused by interaction with natural products (Kovary et al., 2001; Carvalho et al., 2003; Petta et al., 2004; Varela-Barca et al., 2007; Santos et al., 2008). Gel electrophoresis of the plasmid DNA treated with $B$. monandra infusion and with exonuclease III, showed interaction of leaf compounds with the DNA, suggesting a genotoxicity of infusion only at higher concentrations. However, it is not excluded the possibility of this infusion in generate another kind of lesions besides breaks and abasic sites, not observed in electrophoresis. So, it was better investigated transforming the treated plasmid DNA into DH10B cells, deficient in recombinational repair. Neither citotoxicity nor mutagenicity was observed suggesting that $B$. monandra infusion is not able to induce mutagenic lesion in a cell free system.

Studies assess the toxic action of plant extracts through various tests (Silva et al., 2006; Vasconcelos et al., 2007; Dias et al., 2007, Batistuzzo de Medeiros et al., 2003), within which the test is Allium cepa, which is a plant species commonly used to evaluate genotoxicity of chemical and environmental products (Smaka-Kincl et al., 1996; Moreira et al., 2002; Jos et al., 2005; Bagatini et al., 2007; Fachinetto et al., 2007) through the presence of micronuclei (MN), what derived from whole chromosomes or acentric fragments not incorporated into the nucleus during cell division. The chromosome fragments can result from clastogenic effects caused by chemical substances or aneugenic effects where chromosome is lost from mitotic spindles (Yi and Meng, 2003). Cellular activity can also correct errors in cell division, preventing damage to cell genome in the form of micronuclei. According to the ontogenetic structure of the onion, most $\mathrm{MN}$ occurs in F1 cells except in rare cases where there is a delay in mitosis. Studies show greater efficiency when these acentric fragments are analyzed in the $\mathrm{F} 1$ region in relation to the meristematic region, facilitating the score (Yi et al., 2007). This is an efficient system in detecting the clastogenicity of physical agents and chemical products, confirming the non-significance of $B$. monandra infusion analysis in relation to micronuclei found in different infusion concentrations and the lack of mutagenicity in the present approach.

The cytotoxic and genotoxic effects of plant extracts have been studied through years, involving the indiscriminate use of these products, which may be due to their chemical compounds. Secondary metabolites in plants are of great interest at present, whether for their pharmacological, chemical, medicinal or toxic aspects.

The knowledge of the components of a plant from phytochemical selection helps the understanding of its action and its adverse reactions (Andrade et al., 2005; Peitz et al., 2003; Mariz et al, 2006; Carlos et al., 2005). Phytochemical studies of Bauhinia genus confirm the presence of various isolated and identified compounds, including lactones, flavonoids, terpenoids, glycolipids, steroid glycosides, steroids, tannins and quinines (Cechinel-Filho et al., 1996, Silva et al., 2000; Mendes et al., 2006). Bhartiya and Gupta (1981) identified, in $B$. purpurea seeds, the compound: 3.4-dihydroxychalcone4- $O$ - $\beta$-L-arabinopyranosyl- $O$ - $\beta$ - D-galactopyranoside. Previous chemical studies with methanol extract of B. purpurea isolated and identified 6-butil-3hydroxyflavanone (Kuo et al., 1998). Steroid glycosides of $B$. candicans were isolated and identified as: sitosterol 3-O- $\alpha$-D-riburonofuranoside (Irribarren and Pomilio, 1985). In a phytochemical study of $B$. manca, Achenbach et al. (1988) isolated 3-O-galloylepicatechin, one of its primary components. They also identified gallic acid, cinnamic acid, $\beta$ - sitosterol and $\beta$ - D-glucosyl-sitosterol in significant concentrations. Rutin and quercetin were also identified from $B$. splendens leaves (Cechinel-Filho et al., 1996). In B. forficata it was possible to isolate and identify: 3,7-di-O- $\alpha$-(rhamnopyranosylkaempferol, kaempferitrin, and 3,7-di-O- rhamnopyranosylquercetin (Menezes et al., 2007) .

Among $B$. monandra components are: flavonoids, steroids and lectins (Argôlo et al., 2004). Menezes et al. (2007) isolated and identified the compound: $\quad 3,7-$ di- $O$ - $\beta$-rhamnopyranosylquercetin. According to the author, hypoglycemic activity can 


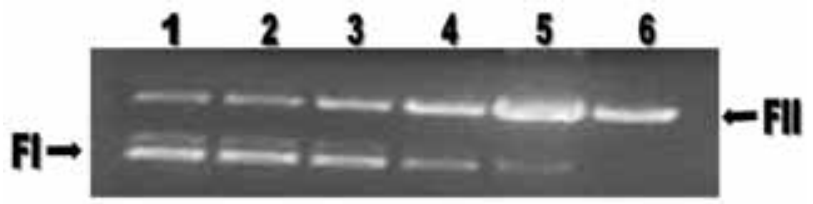

Figure 1. Electrophoretic run in $0.7 \%$ agarose gel of dry $B$. monandra leaf infusion at concentrations: $2(0.8 \mu \mathrm{g} / \mu \mathrm{L}), 3(4 \mu \mathrm{g} /$ $\mu \mathrm{L}), 4(20 \mu \mathrm{g} / \mu \mathrm{L})$ and $5(100 \mu \mathrm{g} / \mu \mathrm{L})$, negative (1) and positive (5) controls. The conformation of plasmid DNA was indicated by form F1 (supercoiled), form FII (nicked circular) and form FIII (linear).

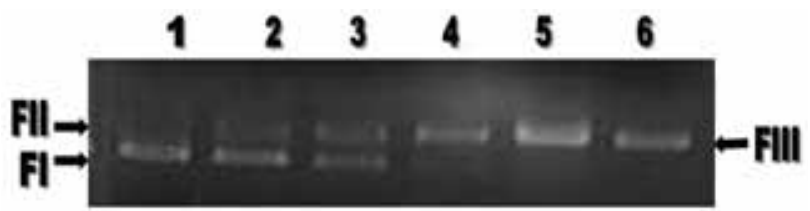

Figure 2. Electrophoresis in $0.7 \%$ agarose gel after treatment of plasmid DNA with exonuclease III enzyme and with infusion of dry B. monandra leaves at concentrations: $2(0.8 \mu \mathrm{g} / \mu \mathrm{L}), 3(4$ $\mu \mathrm{g} / \mu \mathrm{L}), 4(20 \mu \mathrm{g} / \mu \mathrm{L}), 5(100 \mu \mathrm{g} / \mu \mathrm{L})$, negative (1) and positive (2) controls.

Table 1. Result of DH10B bacterial transformation at study concentrations of the infusion of $B$. monandra and leaf infusion negative control (plasmid DNA treated with distilled water).

\begin{tabular}{cc}
\hline Infusion concentration $(\mu \mathrm{g} / \mu \mathrm{L})$ & Bacterial colonies \\
\hline $\mathrm{NC}$ & $7987 \pm 413$ \\
0.8 & $9451 \pm 558$ \\
4 & $9152 \pm 595$ \\
20 & $7021 \pm 306$ \\
100 & $5848 \pm 1.012^{* *}$ \\
\hline
\end{tabular}

NC (Negative control with distilled water), Test performed in triplicate. Mean \pm S.D. $* *$ Significant values $(p<0.01)$ by analysis of variance (ANOVA) and Dunnett test.

Table 2. Result of the Allium cepa test, assessing the presence of micronuclei in the F1 region, after treatment with the infusion of B. monandra at determinate concentrations and after treatment with a negative control (distilled water).

\begin{tabular}{cc}
\hline Concentration $(\mu \mathrm{g} / \mu \mathrm{L})$ & MN in F1 cells \\
\hline $\mathrm{NC}$ & $1.0 \pm 1,7$ \\
0.8 & $0.6 \pm 0.9$ \\
4 & $1.0 \pm 0.7$ \\
20 & $1.2 \pm 1.1$ \\
100 & $1.4 \pm 1.5$ \\
\hline
\end{tabular}

NC (Negative control with distilled water). 15.000 cells analyzed per treatment. Mean \pm S.D. The results showed no significant differences $(p<0.05)$ by analysis of variance (ANOVA) and Dunnett test. be related to the presence of glucosyl flavonoids that have different qualitative and quantitative profiles in extracts. These had a very pronounced effect in the in vitro method used to establish activity, showing them as promising hypoglycemic agents. This study presents similar results in relation to the presence of flavonoids and steroids and identified other components that offer insights into infusion activity, such as: tannins, lactones, triterpenes, resins, alkaloids, organic acids and bases and saponins.

Flavonoids are a phytochemical group with extensive biological activity due to their antioxidant properties and ability to modulate various enzymes and cell receptors; however depending on the number and position of hydroxyl groups in the A and B ring they can act as a mutagenic or a pro-oxidant compound (Skibola and Smith, 2000; Silva et al., 2000; Hodek et al., 2002).

The flavonoid present in the extract (decoction) of stem bark from the pepper tree (Schinus terebinthifolius Raddi) has mutagenic potential as demonstrated by Carvalho et al., (2003) in several bacterial tests, like SOS chromotest, Salmonella reversion assay, and a forward mutagenesis test using CC104 strains of $E$. coli. Flavonoid- enriched fractions and the amentoflavone purified from the decoction of Schinus terebinthifolius Raddi, have shown to be able to damage DNA via oxidative stress producing lesions on DNA that are potential targets of FPG and MutY glycosylase from the base excision repair pathway, confirming the mutagenic potential of this flavonoid (Varela-Barca et al., 2007).

Studies on the free radical-scavenging properties of flavonoids have identified many natural phenol compounds as the main phytochemical antioxidants (Rice-Evans et al., 1997).

According to Argôlo et al. (2004) the antioxidant activity of $B$. monandra leaves is suggested by the presence of flavonoids and steroids. This may impact on the prevention of chronic cardiovascular and neoplastic diseases, neurodegenerative diseases such as Parkinson's and Alzheimer's, as well as immunological dysfunctions, premature aging and cancer. $B$. monandra also contains tannins, which were found to have antimutagenic properties according to many published studies (Deguchi et al., 2001; Chen and Chung, 2000) and saponins, reported in some studies as non-mutagenic or antimutagenic (Scarpato et. al., 1998; Berhow et al., 2000).

Species of the same genus such as B. galpinii, B. purpurea (Codington et al., 1975) and B. variegata (Rajkapoor et al., 2003) have been described as antimutagenic.

The infusion of dried B. monandra leaves was found to be genotoxic with in vitro experiments, at usual concentrations $(100 \mu \mathrm{g} / \mu \mathrm{L})$. However, it did not cause cytotoxicity or mutagenicity in tests where concentrations were determined by the study. This demonstrates

Rev. Bras. Farmacogn. Braz J. Pharmacogn 18(4): Out./Dez. 2008 
the feasibility of its use and commercialization as a hypoglycemic for oral use with medical follow-up, in order to be employed correctly and reasonably as a phytotherapeutic.

We can therefore conclude that the $B$. monandra Kurtz infusion was able to cause breaks in the phosphodiester DNA bonds and form abasic sites but only at the highest concentrations tested, which does not represent a therapeutic dose. This action can be explained by the presence of phenol hydroxyls in positions 3' and 4' of ring B and free hydroxyls or methoxyl groups in position 7 of ring A. However, the infusion did not cause cytotoxicity or mutagenicity in any of the concentrations tested, which may be due to the presence of tannins, steroids, lecithins, saponins, antimutagenic flavonoids.

The non mutagenic effects observed in the two in vivo systems used, E. coli and Allium cepa, is very interesting since this infusion has shown a potent hypoglycemiant effect.

\section{ACKNOWLEDGMENTS}

The authors are grateful to Dr. Lucymara Fasarella Agnez Lima and Dr. Katia Castanho Scortecci and to the Departamento de Biologia Celular e Genética, UFRN, Brazil, for their important contribution to the beginning of this study. The first author is grateful to the students of the LAMA (Laboratório de Mutagênese Ambiental) and LBMG (Laboratório de Biologia Celular e Genética), UFRN, Brazil, for their assistance in performing the assays and want to thank in particular her parents Francisco de Sales Macêdo and Maria de Fatima Silva Macêdo. The authors express their gratitude to the Conselho Nacional de Desenvolvimento Científico e Tecnológico (CNPq) for research grants and fellowship (LCBBC and SRBM).

\section{REFERENCES}

Achenbach H, Stocker M, Constela MA 1988. Flavonoid and other constituents of Bauhinia manca. Phytochemistry 27: 1835-1841.

Agner AR, Maciel MA, Pinto AC, Pamplona SG, Colus IM 1999. Investigation of genotoxic activity of transdehydrocrotonin, a clerodane triterpene fom Croton cajucara. Teratogen Carcin Mutagen 19: 377-384.

Agra MF, França PF, Barbosa-Filho JM 2007. Synopsis of the plants known as medicinal and poisonous in Northeast of Brazil. Rev Bras Farmacogn 17: 114 140.

Agra MF, Silva KN, Basílio IJLD, França PF, Barbosa-Filho JM 2008. Survey of medicinal plants used in the region Northeast of Brazil. Rev Bras Farmacogn 18: 472-508.

Andrade CA, Peitz C, Cúnico M, Carvalho JLS, Abrahão WM, Miguel OG, Miguel MD, Kerber VA 2005. Avaliação da atividade antibacteriana e triagem fitoquímica das flores de Acacia podalyriifolia A. Cunn. ex G. Don
Leguminosae-Mimosoideae. Rev Bras Farmacogn 15: 13-15.

Argôlo AC, Santa'ana AE, Pletsch M, Coelho LC 2004. Antioxidant activity of leaf extracts from Bauhinia. Bioresour Technol 95: 229-233.

Bagatini MD, Silva ACF, Tedesco SB 2007. Uso do sistema teste de Allium cepa como bioindicador de genotoxicidade de infusões de plantas medicinais. Rev Bras Farmacogn 17: 444-447.

Berhow MA, Wagner ED, Vaughn SF, Plewa MJ 2000. Caracterization and antimutagenic activity of soybean saponins. Mutat Res 448: 11-22.

Bhartiya HP, Gupta PC 1981. A chalcone glycoside from the seeds of Bauhinia purpurea. Phytochemistry 20: 2051-2051.

Cardoso CR, Syllos-Colus IM, Bernardi CC, Sannomiya M, Vilegas W, Varanda EA 2006. Mutagenic activity promoted by amentoflavone and methanolic extract of Byrsonima crassa Niedenzu. Toxicology 225: 5563.

Carlos IZ, Lopes FCM, Benzatti FP, Carli CBA, Marques MF, Jordão CM 2005. Ação do extrato metanólico e etanólico de Davilla elliptica St. Hill. (Malpighiaceae) na resposta imune. Rev Bras Farmacogn 15: 44-50.

Carvalho MCRD, Barca FNTV, Agnez-Lima LF, Batistuzzo de Medeiros SR 2003. Evaluation of mutagenic activity in the extract of pepper tree stem bark (Schinus terebinthifolius Raddi). Environ Mol Mutagen 42: 185-191.

Cechinel Filho V, Breviglieri E, Filho AW, Santos ARS 1996. Estudo fitoquímico e avaliação preliminar da atividade analgésica de Bauhinia splendens. Rev Bras Farm 76: 115-117.

Chan K 2003. Some aspects of toxic contaminants in herbal medicines. Chemosphere 52: 1361-1371.

Chen S, Chung K 2000. Mutagenicity and antimutagenicuty studies of tannic acid and its related compounds. Food Chem Toxicol 38: 1-5.

Codington JF, Cooper AG, Brown MC, Jeanloz RW 1975. Evidence that the major cell suface glycoprotein of the TA3-Ha carcinoma contains the Vicia graminea receptor sites. Biochemistry 14: 855-859.

Deguchi TYM, Ohba R, Ueda S 2001. Antimutagenicity of the purple pigment, hordeumin, from uncooked barley bran-fermented broth. Biosci Biotech Biochem 64: 414-416.

Dias KS, Almeida DS, Silva ABL et al. 2007. Avaliação dos efeitos miorelaxante, antiespasmódico e antinociceptivo do extrato aquoso da Phoradendron piperoides (Kunt.) Trel. (Viscaceae). Rev Bras Farmacogn 17: 373-377.

Fachinetto JM, Bagatini MD, Durigon J, da Silva ACF, Tedesco SB 2007. Efeito anti-proliferativo das infusões de Achyrocline satureioides DC (Asteraceae) sobre o ciclo celular de Allium cepa. Rev Bras Farmacogn 17: 49-54.

Farmacopéia dos Estados Unidos do Brasil. 1959. 2nd ed. São Paulo: Indústria Gráfica Siqueira; 1265.

Flieger A, Rydzewski K, Banerji S, Broich M, Heuner K 2004. Cloning and characterization of the gene encoding the major cell-associated phospholipase A of Legionella pneumophila, plaB, exhibiting hemolytic activity. Infect Immun 72: 2648-2658. 
Hodek P, Trefil P, Stiborova M 2002. Flavonoids-potent and versatile biologically active compounds interacting with cytochromes P450. Chem Biol Interact 139: $1-21$.

Irribarren AM, Pomilio AB 1985. Sitosterol 3-O- $\beta$ dibutanofuranoside from Bauhinia candicans. Phytochemistry 24: 360-361

Jos A, Repetto G, Ríos JC, del Peso A, Salguero M, Hazen M.J, Moleno ML, Fernández-Freire P, Pérez-Martin M, Labrador V, Cameán A 2005. Ecotoxicological evaluation of the additive butylated hydroxyanisole using a battery with six model systems and eighteen endpoints. Aquat Toxicol 71: 183-192.

Kovary K, Louvain TS, Costa e Silva MC, Albano F, Pires BB, Laranja GA, Lage CL, Felzenszwalb I 2001. Biochemical behaviour of norbixin during in vitro DNA damage induced by reactive oxygen species. Brit J Nutr 85: 431-440.

Kuo Y, Yeh M, Huang S 1998. A novel 6-butyl-3- hydroxyfl avanone from heartwood of Bauhinia purpurea. Phytochemistry 49: 2529-2530.

Lamba SS, Buch KY, Lewis H, Lamba HJ 2000. Phytochemicals as potential hypoglycemic agents. Studies in Natural Products Chemistry 21: 457-495.

Ma TH, Xu Z, Xu C, Mcconnell H, Rabago EV, Arreola GA, Zhang H 1995. The improved Allium and Vicia root tip micronucleus assay for clastogenicity of environmental pollutants. Mutat Res 334: 185-195.

Macedo M, Ferreira AR 2004. Plantas hipoglicemiantes utilizadas por comunidades tradicionais na Bacia do Alto Paraguai e Vale do Guaporé, Mato GrossoBrasil. Rev Bras Farmacogn 14: 45-47.

Mariz SR, Cerqueira GS, Araújo WC, Duarte JC, Melo AFM, Santos HS, Oliveira K, Diniz MFFM, Medeiros IA 2006. Estudo toxicológico agudo do extrato etanólico de partes aéreas de Jatropha gossypiifolia L. em ratos. Rev Bras Farmacogn 16: 372-378.

Marques RCP, Batistuzzo de Medeiros SR, Dias CS, BarbosaFilho JM, Agnez-Lima LF 2003. Evaluation of the mutagenic potential of yangambin and of the hydroalcoholic extract of Ocotea duckei by the Ames test. Mutat Res-Genet Toxicol Environ Mutagen 536: $117-120$

Matos F.J.A 2000. Plantas medicinais: guia de seleção e emprego de plantas usadas em fitoterapia no Nordeste do Brasil. 2. ed. Fortaleza.

Mendes BG, Machado MJ, Falkenberg M 2006. Triagem de glicolipídios em plantas medicinais. Rev Bras Farmacogn 16: 568-575.

Menezes FS, Minto ABM, Ruela HS, Kuster RM, Sheridan H, Frankish N 2007. Hypoglycemic activity of two Brazilian Bauhinia species: Bauhinia forficata L. and Bauhinia monandra Kurz. Rev Bras Farmacogn 17: 8-13.

Minto ABM, Pereira MA 2000. XVI Latinoamerican Congress of Pharmacology, Águas de Lindóia, Brasil.

Miyake ET, Akisue G, Akisue MK 1986. Pharmacognostic characterization of pata-de-vaca (Bauhinia forficata). Rev Bras Farmacogn 1: 56-58.

Morais SM, Dantas JDP, Silva ARA, Magalhães EF 2005. Plantas medicinais usadas pelos índios Tapebas do Ceará. Rev Bras Farmacogn 15: 169-177.

Moreira RRD, Santos LE, Varella SD, Varanda EA, Vilegas
W 2002. Avaliação da atividade mutagênica do extrato etanólico bruto de Paepalanthus latipes (Eriocaulaceae) e dos compostos flavonoídicos 7-metoxilados relacionados. Rev Bras Farmacogn 12: 11-19.

Peitz C, Cúnico MM, Miguel OG, Miguel MD, Kerber VA 2003. Avaliação da atividade antibacteriana e triagem fitoquímica das folhas de Acacia longifolia (Andr.) Willd. (Leguminosae). Rev Bras Farmacogn 13: 6165.

Pereira RC, Oliveira MTR, Lemos GCS 2004. Plantas utilizadas como medicinais no município de Campos de Goytacazes - RJ. Rev Bras Farmacogn 14: 37 40.

Perez Gutiérrez RM 2002. Compuestos aislados de plantas com actividad antiinflamatoria, antiviral $e$ hipoglicemiante. México: Instituto Politécnico Nacional; 139-185.

Petta TB, Batistuzzo de Medeiros SR, Egito EST, Agnez-Lima LF 2004. Genotoxicity induced by saponified coconut oil surfactant in prokaryote systems. Mutagenesis 19: 441-444

Rajkapoor B, Jayakar B, Murugesh N 2003.Antitumour activity of Bauhinia variegata on Dalton's ascitic lymphoma. J Ethnopharmacol 89: 107-109.

Rice-Evans CA, Miller NJ, Paganga G 1997. Antioxidant properties of phenolic compounds. Trends Plant Sci 2: $152-159$

Reid KA, Maes J, Maes A, Van Staden J, de Kimpe N, Mulholland DA,Verschaeve L 2006. Evaluation of the mutagenic and antimutagenic effects of South African plants. $J$ Ethnopharmacol 106: 44-50.

Ritter MR, Sobierajski GR, Schenkel EP, Menth LA 2002. Plantas usadas como medicinais no município de Ipê, RS, Brasil. Rev Bras Farmacogn 12: 51-62.

Sambrook J, Fritsch EF, Maniatis T 1989. Molecular Cloning: A Laboratory Manual, 3rd ed. Plainview, NY: Cold Spring Harbor Laboratory.

Santos PE, Egito LCM, Batistuzzo de Medeiros SR, AgnezLima LF 2008.Genotoxicity Induced by Eugenia caryophyllata infusion. $J$ Toxicol Environ Health Part A 71: 439-444.

Scarpato R, Bertoli A, Naccarati A, Migliore L, Cocchi L, Barale R, Pistelli L 1998. Different effects of newly isolated saponins on the mutagenicity and cytotoxicity of the anticancer drugs mitomycin $\mathrm{C}$ and bleomycin in human lymphocytes. Mutat Res 420: 49-54.

Silva KL, Biavatti MW, Leite SN, Yunes RA, Monache F, Cechinel-Filho V 2000. Phytochemical and pharmacognostic investigation of Bauhinia forficata. Link. Z Naturforsch C 55: 478-480.

Silva MIG, Gondim APS, Nunes IFS, Sousa FCF 2006. Utilização de fitoterápicos nas unidades básicas de atenção à saúde da família no município de Maracanaú (CE). Rev Bras Farmacogn 16: 455-462.

Sokal RR, Rohlf KJ 1995. Biometry: the principles and practices of statistics in biological research. 3rd ed. New York: WA Freeman; 887.

Skibola CF, Smith MT 2000. Potential health impacts of excessive flavonoid intake. Free Radical Biol Med 29: 375-383.

Smaka-Kincl V, Stegnar P, Lovka M, Toman MJ 1996. The evaluation of waste, surface and ground water 
quality using the Allium test procedure. Mutat Res 368: 1719 .

Varela-Barca FNT, Agnez-Lima LF, Batistuzzo de Medeiros SR 2007. Base excision repair pathway is involved in the repair of lesions generated by flavonoid-enriched fractions of pepper tree (Schinus terebinthifolius, Raddi) stem bark. Environ Mol Mutagen 48: 672681.

Vasconcelos THC, Modesto-Filho J, Diniz MFFM, Santos HB, Aguiar FB, Moreira PVL 2007. Estudo toxicológico pré-clínico agudo com o extrato hidroalcoólico das folhas de Cissus sicyoides L. (Vitaceae). Rev Bras Farmacogn 17: 583-591.

WHO 2000. Organización Mundial de La Salud. Situación regulamentaria de los medicamentos: uma resena mundial. Traducción del inglés: Organización Panamericana de la Salud. Washington: OPAS; 62.

Yi Z, Meng H 2003.Genotoxicity of hydrated sulfur dioxide on root tips of Allium sativum and Vicia faba. Mutat Res 537: 109-114.

Yi H, Wu L, Jiang L 2007. Genotoxicity of arsenic evaluated by Allium-root micronucleus assay. Sci Total Environ 383: 232-236. 